\title{
Genome sequence of a high agarase- producing strain Flammeovirga sp. SJP92
}

\author{
Qi Dong ${ }^{1,2,3,4}$, Lingwei Ruan ${ }^{1,2,3,4^{*}}$ and Hong Shi $i^{1,2,3,4}$
}

\begin{abstract}
Flammeovirga sp. SJP92 is a Gram-negative, aerobic, rod-shaped, non-motile and non-flagellated strain that belongs to the family Flammeovirgaceae of the class Cytophagia. The strain was isolated from the intestine of abalone, which produces many extracellular agarases and exhibits efficient degradation activities on various polysaccharides, especially agarose. Here we present the high-quality draft genome of Flammeovirga sp. SJP92, together with its phenotypic characteristics. The genome sequence is $8,534,834 \mathrm{bp}$, which comprised with one chromosome and no plasmid. It contained 6, 291 protein-coding and 99 RNA genes, including 93 tRNA, 5 rRNA and 1 ncRNA genes.
\end{abstract}

Keywords: Flammeovirga, Genome, High agarase-producing

\section{Introduction}

Flammeovirga is one of genera belonging to the family Flammeovirgaceae of the class Cytophagia. There are five species have been reported in this genus, including $F$. aprica [1], F. arenaria, F. yaeyamensis [2], F. kamogawensis [3] and F. pacifica [4]. They are all marine bacterium and have a potent ability to degrade marine complex polysaccharides, such as agar, carrageenan [3,5-8]. Among them, only two draft genome sequences have been published [9], namely Flammeovirga sp. OC4 (NZ_JTAM01000001.1) [5] and . pacifica WPAGA1 ${ }^{\mathrm{T}}$ (=CCTCC AB 2010364T=LMG 26175T =DSM 24597T =MCCC 1A06425T) [7].

Flammeovirga sp. SJP92 with high-producing agarase was isolated and identified from the intestine of abalone in Xiamen, China. It is closely related with Flammeovirga sp. NBRC 100896 (AB681288.1) and shared 99\% similarities of $16 \mathrm{~S}$ rRNA. In order to provide more genome information of Flammeovirga species and realize the function of Flammeovirga sp. SJP92 when degradingmarine complex polysaccharides, the genome of Flammeovirga sp. SJP92 was sequenced. In this study, we summarized its genomic characteristics, as well as general phenotypic properties.

\footnotetext{
* Correspondence: ruanlingwei@tio.org.cn

'State Key Laboratory Breeding Base of Marine Genetic Resources, No. 184

Daxue Road, Xiamen, Fujian, People's Republic of China

${ }^{2}$ Key Laboratory of Marine Genetic Resources of State Oceanic

Administration, Third Institute of Oceanography, State Oceanic

Administration, No. 184 Daxue Road, Xiamen, Fujian, People's Republic of

China

Full list of author information is available at the end of the article
}

Other species of Flammeovirga genus were also compared with Flammeovirga sp. SJP92 in both phenotypic and genomic aspects.

\section{Organism information \\ Classification and features}

Flammeovirga sp. SJP92 was isolated from the digestion guts of abalone with high agar-degrading ability, and deposited in China General Microbiological Culture Collection Center (CGMCC 10071). Based on the phylogenetic tree constructed with $16 \mathrm{~S}$ rRNA, Flammeovirga sp. SJP92 is closely related with Flammeovirga sp. NBRC 100896 (AB681288.1) (Fig. 1). It is Gram-negative, curved-rods $(0.75 \mu \mathrm{m}$ wide and $11-13 \mu \mathrm{m}$ long) after growth on $2216 \mathrm{E}$ plate for 3 days at $30^{\circ} \mathrm{C}$. It is aerobic and not motile without any flagella (Fig. 2). Also it is able to utilize a relatively wide spectrum of carbon substrates for growth, including agar, starch, carrageenan, L-fructose, Tween40, Tween80, galactose, lactose and so on, but it cannot utilize cellulose. Its growth temperature ranges from 15 to $40{ }^{\circ} \mathrm{C}$ with optimum between 25 and $30{ }^{\circ} \mathrm{C}$. In addition, the optimum salinities for the growth of Flammeovirga sp. SJP92 were $2 \sim 4 \%$ (Table 1). When compared with other Flammeovirga species, this strain is different from F. pacifica WPAGA $1^{\mathrm{T}}$ [8] and F. aprica NBRC $15941 \mathrm{~T}$ [2] in catalase, urease and esterase lipase and in the utilization of starch, D-Mannitol, Lfructose, Tween $40 \& 80$ and D-xylose, differences were also observed in growth temperature range (Table 2). 


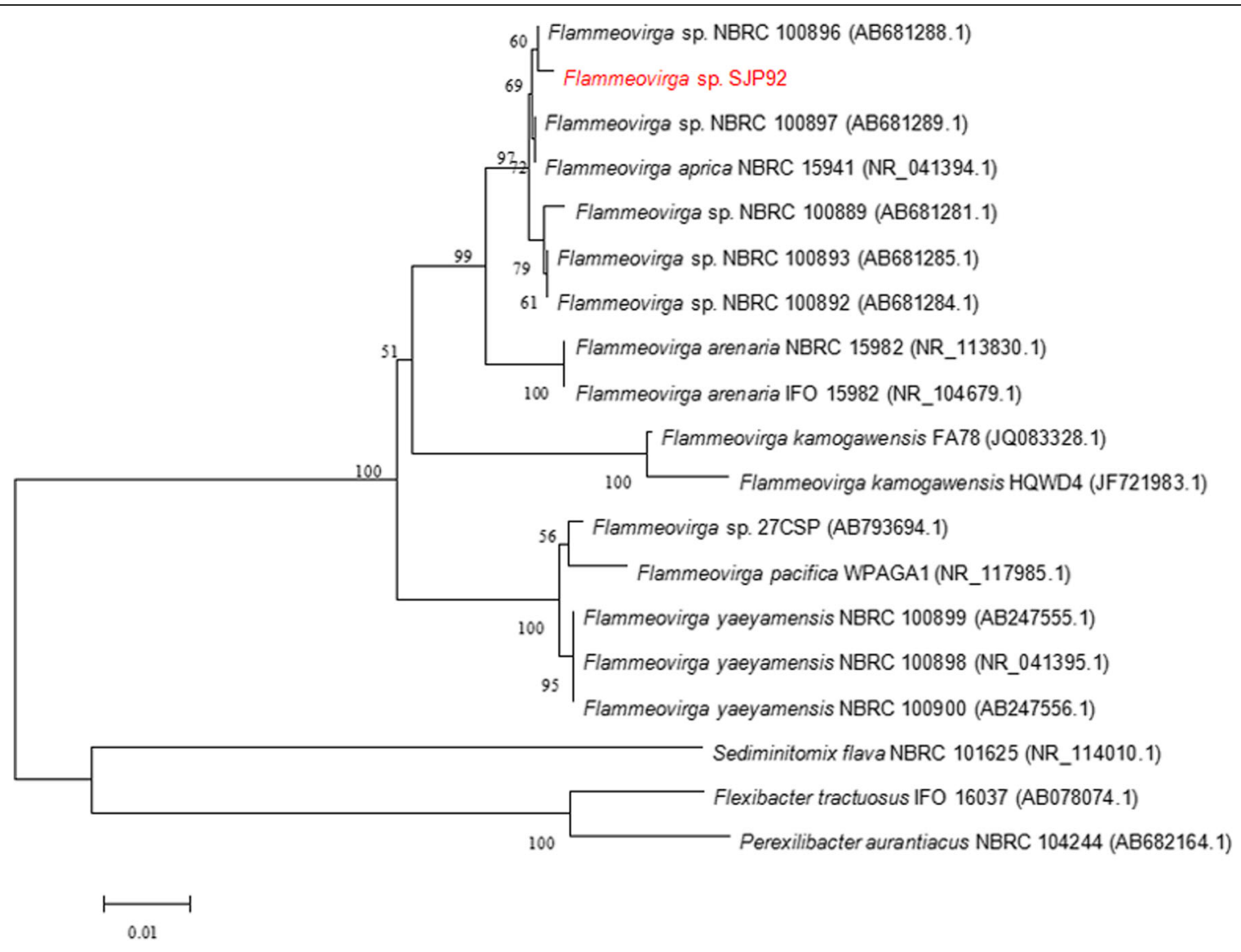

Fig. 1 Phylogenetic tree highlighting the position of Flammeovirga sp. SJP92 relative to other type and non-type strains with finished or non-contiguous finished genome sequences within the family Flammeovirga. Accession numbers of $16 \mathrm{~S}$ rRNA gene sequences are indicated in brackets. Sequences were aligned using ClustalX [14] and a neighbor-joining tree obtained using the maximum-likelihood method within the MEGA version4.0 [20]. Numbers adjacent to the branches represent percentage bootstrap values based on 1000 replicates

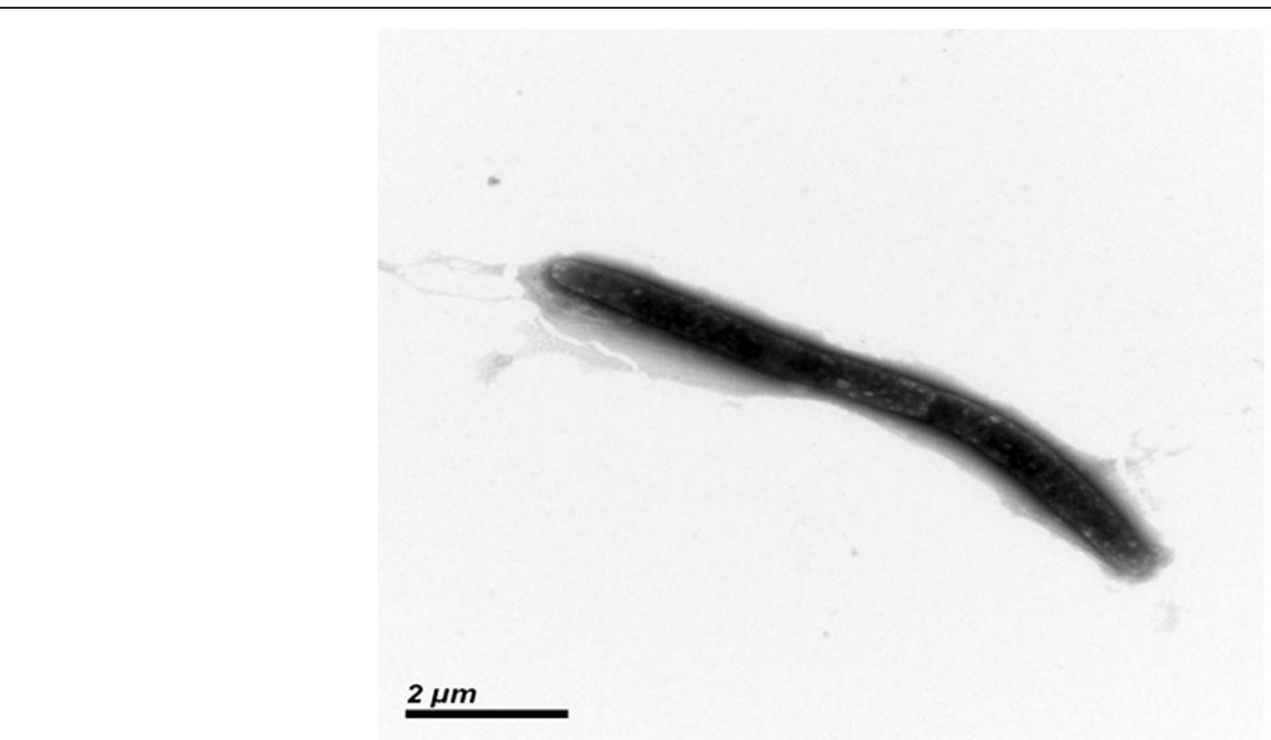

Fig. 2 Transmission electron micrograph of Flammeovirga sp. SJP92, using a JEM-100CX at an operating voltage of $120 \mathrm{KV}$. The scale bar represents $2 \mu \mathrm{m}$ 
Table 1 Classification and general features of Flammeovirga sp.SJP92

\begin{tabular}{|c|c|c|c|}
\hline MIGS ID & Property & Term & $\begin{array}{l}\text { Evidence } \\
\text { Code }^{\mathrm{a}}\end{array}$ \\
\hline & Current classification & Domain Bacteria & TAS [21] \\
\hline & & Phylum Bacteroidetes & TAS [22] \\
\hline & & Class Cytophagia & $\operatorname{TAS}[23,24]$ \\
\hline & & Order Cytophagales & $\operatorname{TAS}[25,26]$ \\
\hline & & Family Flammeovirgaceae & TAS [27] \\
\hline & & Genus Flammeovirga & TAS [1] \\
\hline & & Species Flammeovirga sp. & $\operatorname{TAS}[5,7]$ \\
\hline & & Strain SJP92 & IDA \\
\hline & Gram Stain & Negative & IDA \\
\hline & Cell shape & Curved-rods & IDA \\
\hline & Motility & None & IDA \\
\hline & Sporulation & Non-sporulating & IDA \\
\hline & $\begin{array}{l}\text { Temperature } \\
\text { range }\end{array}$ & $15 \sim 40{ }^{\circ} \mathrm{C}$ & IDA \\
\hline & $\begin{array}{l}\text { Optimum } \\
\text { temperature }\end{array}$ & $25 \sim 30^{\circ} \mathrm{C}$ & IDA \\
\hline & $\begin{array}{l}\text { pH range; } \\
\text { Optimum }\end{array}$ & $5 \sim 9,8$ & IDA \\
\hline & Carbon source & $\begin{array}{l}\text { Agar, Starch, Carrageenan, } \\
\text { D-galactose, L-fructose, } \\
\text { Tween } 40 \& 80\end{array}$ & IDA \\
\hline MIGS-6 & Habitat & Intestinal tract & IDA \\
\hline MIGS-6.3 & Salinity & $0.5-8 \% \mathrm{NaCl}(\mathrm{w} / \mathrm{v})$ & IDA \\
\hline MIGS-22 & Oxygen & Aerobic & IDA \\
\hline MIGS-15 & Biotic relationship & Free-living & IDA \\
\hline MIGS-14 & Pathogenicity & Unknown & NAS \\
\hline MIGS-4 & $\begin{array}{l}\text { Geographic } \\
\text { location }\end{array}$ & Xamen city, China & IDA \\
\hline MIGS-5 & Sample collection & October 2006 & IDA \\
\hline MIGS-4.1 & Latitude & $24^{\circ} 26^{\prime}$ & IDA \\
\hline MIGS-4.2 & Longitude & $118^{\circ} 04^{\prime}$ & IDA \\
\hline MIGS-4.4 & Altitude & Sea level & IDA \\
\hline
\end{tabular}

avidence codes: IDA Inferred from Direct Assay, TAS Traceable Author Statement (i.e., a direct report exists in the literature), NAS Non-traceable Author Statement (i.e., not directly observed for the living, isolated sample, but based on a generally accepted property for the species, or anecdotal evidence). These evidence codes are from the Gene Ontology project [28] If the evidence code is IDA, then the property should have been directly observed for a live isolate by one of the authors, or an expert or reputable institution mentioned in the acknowledgement

\section{Genome sequencing information} Genome project history

This organism was initially selected for sequencing on the basis of its high agar-degrading ability. Sequencing of the Flammeovirga sp. SJP92 genome was performed at the Beijing Novogene Bioinformatics Technology Co., Ltd. The Whole Genome Shotgun project has been deposited at the DDBJ/EMBL/GenBank database under the accession
Table 2 Differential phenotypic characteristics between Flammeovirga sp. S.JP92 and other Flammeovirga species

\begin{tabular}{|c|c|c|c|}
\hline Characteristic & 1 & 2 & 3 \\
\hline $\begin{array}{l}\text { Cell diameter } \\
\text { (um) }\end{array}$ & $11 \sim 13 \times 0.75$ & $3.0 \sim 8.0 \times 0.5 \sim 0.8$ & $1.7 \sim 96 \times 0.5 \sim 0.9$ \\
\hline $\begin{array}{l}\text { Salinity/ } \\
\text { Optimum(w/v) }\end{array}$ & $0.5 \sim 8 \% / 2 \sim 4 \%$ & $0-5 \% / 3 \%$ & $1-5 \% / 3 \%$ \\
\hline $\begin{array}{l}\text { Temperature } \\
\text { range }\left({ }^{\circ} \mathrm{C}\right)\end{array}$ & $15 \sim 40$ & $4-42$ & $15-30$ \\
\hline $\begin{array}{l}\text { Number of polar } \\
\text { flagella }\end{array}$ & None & None & None \\
\hline \multicolumn{4}{|l|}{ Production of } \\
\hline Agarase & + & + & + \\
\hline Catalase & + & - & - \\
\hline Oxidase & + & + & + \\
\hline Esterase lipase & - & \pm & \pm \\
\hline Urease & + & - & - \\
\hline$\beta$-Galactosidase & + & \pm & ND \\
\hline a-Galactosidase & + & + & ND \\
\hline $\begin{array}{l}\text { Nitrate } \\
\text { reductase }\end{array}$ & + & + & + \\
\hline $\begin{array}{l}\text { Alkaline/Acid } \\
\text { phosphatase }\end{array}$ & + & + & + \\
\hline \multicolumn{4}{|l|}{ Carbon source } \\
\hline Gelatin & ND & - & - \\
\hline Agar & + & + & + \\
\hline Starch & + & - & - \\
\hline Cellulose & - & - & - \\
\hline D-galactose & + & + & + \\
\hline D-Mannitol & - & \pm & - \\
\hline L-fructose & + & + & - \\
\hline Tween40\&80 & + & - & - \\
\hline D-xylose & - & + & + \\
\hline $\begin{array}{l}\text { Geographic } \\
\text { location }\end{array}$ & $\begin{array}{l}\text { XiaMen, } \\
\text { China }\end{array}$ & $\begin{array}{l}157^{\circ} 249^{\prime} 310^{\prime \prime} \mathrm{E} \\
19^{\circ} 309^{\prime} 300^{\prime \prime} N\end{array}$ & $\begin{array}{l}\text { Iriomote/Ishigaki } \\
\text { Islands }\end{array}$ \\
\hline Habitat & $\begin{array}{l}\text { Intestinal } \\
\text { tract }\end{array}$ & $\begin{array}{l}\text { Deep-sea } \\
\text { sediment }\end{array}$ & $\begin{array}{l}\text { Seaweeds/coastal } \\
\text { sands/dead leaves }\end{array}$ \\
\hline
\end{tabular}

Strains: 1, Flammeovirga sp. SJP92; 2, F. pacifica $\mathrm{WPAGA1}^{\top} ; 3$, F. aprica NBRC15941 ${ }^{\top}$.+: positive result, - : negative result, \pm :weak positive result, $N D$ no data available

number LQAQ00000000. The project information and its association with MIGS version 2.0 compliance were presented in Table 3 [9].

\section{Growth conditions and genomic DNA preparation}

Flammeovirga sp. SJP92 was incubated aerobically in the modified 2216E medium $\left(2.2 \% \mathrm{NaCl}, 0.365 \% \mathrm{MgCl}_{2} .6 \mathrm{H}_{2} \mathrm{O}\right.$, $0.729 \% \mathrm{MgSO}_{4} \cdot 7 \mathrm{H}_{2} \mathrm{O}, 0.03 \% \mathrm{CaCl}_{2} \cdot 2 \mathrm{H}_{2} \mathrm{O}, 0.05 \% \mathrm{KCl}$, $0.042 \% \quad \mathrm{KH}_{2} \mathrm{PO}_{4}, \quad 0.005 \% \mathrm{NaBr}, \quad 0.002 \% \quad \mathrm{SrCl} \cdot 6 \mathrm{H}_{2} \mathrm{O}$, $0.002 \% \mathrm{Fe}\left(\mathrm{NH}_{4}\right)$ Citrate, $1.326 \%$ tryptone) supplied with $0.2 \%$ agar. After incubation at $32{ }^{\circ} \mathrm{C}, 200 \mathrm{rpm}$ for $24 \mathrm{~h}$, the bacteria was collected at $13000 \mathrm{rpm}$ for $30-60 \mathrm{~min}$ at $4{ }^{\circ} \mathrm{C}$. 
Table 3 Genome sequencing project information for Flammeovirga sp. SJP92

\begin{tabular}{lll}
\hline MIGS ID & Property & Term \\
\hline MIGS-31 & Finishing quality & High-quality draft \\
MIGS-28 & Libraries used & $\begin{array}{l}500 \text { bp pair-end\&5 kb } \\
\text { mate-end libraries }\end{array}$ \\
MIGS-29 & Sequencing platforms & Illumina HiSeq2500, \\
MIGS-31.2 & Fold coverage & 215× \\
MIGS-30 & Assemblers & SOAPdenovo v.2.04 \\
MIGS-32 & Gene calling method & NCBI PGAP pipeline \\
& Locus Tag & AVL50 \\
& GenBank ID & LQAQ00000000 \\
& GenBank Date of Release & March 9th, 2016 \\
& GOLD ID & NA \\
& BIOPROJECT & PRJNA306821 \\
& Source Material identifier & SJP92 \\
MIGS-13 & Project relevance & Agriculture, industry \\
\hline
\end{tabular}

The CTAB/NaCl method [10] was used for the extraction of chromosomal DNA of Flammeovirga sp. SJP92.

\section{Genome sequencing and assembly}

The genome of Flammeovirga sp. SJP92 was sequenced with MPS (massively parallel sequencing) Illumina technology. Three DNA libraries were constructed: a pairedend library with an insert size of $500 \mathrm{bp}$ and two matepair libraries with an insert size of $5 \mathrm{~kb}$. The $500 \mathrm{bp}$ library and the $5 \mathrm{~kb}$ libraries were sequenced using an Illumina HiSeq2500 by PE125 strategy. Library construction and sequencing was performed at the Beijing Novogene Bioinformatics Technology Co., Ltd. Quality control of both paired-end and mate-pair reads were performed using in-house program. The final coverage reached 215folds of the genome. SOAPdenovo [11, 12] was used for sequence assembly, and the final assembly yielded 123 contigs which generated a genome of $8.53 \mathrm{Mb}$.

\section{Genome annotation}

The genes of Flammeovirga sp. SJP92 was identified by NCBI Prokaryotic Genome Annotation Pipeline server online [13]. Functional predicted was performed by comparing them with sequences in RPS-BLAST against Clusters of Orthologous Groups database and pfam database [14-16]. SignalP was used to predict signal peptide [17], and transmembrane helice was analyzed by TMHMM program [18]. CRISPRFinder was used for CRISPR identification [19].

\section{Genome properties}

The Flammeovirga sp. SJP92 genome has only one circular chromosome of a total size of about 8, 534,
834 bp with a $34.80 \%$ GC content (containing 123 contigs, 44 scaffolds).6519 genes were predicted, of which 6291 genes were protein-coding genes. 2660 genes (40.8\%) were assigned to putative function and annotated as hypothetical proteins. And 99 RNAs (including 93 tRNAs, 5 rRNAs and 1 ncRNA), 127 pseudo genes were also identified. The properties and the statistics of the genome were summarized in Table 4, and Table 5 presented the distribution of genes into COGs functional categories. 3752 genes (57.55\%) were assigned to COG functional categories, the most abundant COG category was "General function prediction only" (561 proteins) followed by "Signal transduction mechanisms" (401 proteins), "Transcription" (382 proteins), "Function unknown" (350 proteins), "Cell wall/membrane/envelope biogenesis" (347 proteins), "Inorganic ion transport and metabolism" (318 proteins), and "Carbohydrate transport and metabolism" (306 proteins).

\section{Insights from the genome sequence}

Until now, only two genome sequences of the strain $F$. pacifica WPAGA $1^{\mathrm{T}}$ and Flammeovirga sp. OC4 were available within the genus Flammeovirga. Here, a whole genome comparison with these three strains have been done (Table 6). The genome of Flammeovirga sp. SJP92 is nearly $2 \mathrm{Mb}$ bigger in size than F. pacifica WPAGA1 ${ }^{\mathrm{T}}$, but almost the same as Flammeovirga sp. OC4. The G+C content of Flammeovirga sp. SJP92 (34.8\%) is slightly different with $F$. pacifica WPAGA $1^{\mathrm{T}}$ (33.8\%) and Flammeovirga sp. OC4 (34.9\%). The gene number of Flammeovirga sp. SJP92 is different from these two strains $(6,519$ \& 4, 857 \& 5, 898).

Table 4 Genome Statistics for Flammeovirga sp. SJP92

\begin{tabular}{lll}
\hline Attribute & Value & \% of Total \\
\hline Genome size (bp) & $8,534,834$ & 100.0 \\
DNA coding (bp) & $7,309,656$ & 85.64 \\
DNA G + C (bp) & $2,970,122$ & 34.80 \\
DNA scaffolds & 44 & 100.00 \\
Total genes & 6519 & 100.00 \\
Protein-coding genes & 6291 & 96.5 \\
RNA genes & 99 & 1.52 \\
Pseudo genes & 127 & 1.95 \\
Genes in internal clusters & NA & NA \\
Genes with function prediction & 4240 & 65.04 \\
Genes assigned to COGs & 3752 & 57.55 \\
Genes assigned Pfam domains & 3964 & 60.81 \\
Genes with signal peptides & 1658 & 25.43 \\
Genes with transmembrane helices & 1510 & 23.16 \\
CRISPR repeats & 1 & 0.01 \\
\hline
\end{tabular}

${ }^{\text {a }}$ The total is based on either the size of the genome in base pairs or on the total number of protein coding genes in the annotated genome $N A$ not available 
Table 5 Number of protein coding gene of Flammeovirga sp. SJP92 associated with COG functional categories

\begin{tabular}{|c|c|c|c|}
\hline Code & value & $\%$ age & Description \\
\hline J & 178 & 2.83 & Translation, ribosomal structure and biogenesis \\
\hline A & 0 & 0 & RNA processing and modification \\
\hline K & 382 & 6.07 & Transcription \\
\hline L & 199 & 3.16 & Replication, recombination and repair \\
\hline B & 2 & 0.03 & Chromatin structure and dynamics \\
\hline D & 47 & 0.75 & $\begin{array}{l}\text { Cell cycle control, cell division, chromosome } \\
\text { partitioning }\end{array}$ \\
\hline V & 90 & 1.43 & Defense mechanisms \\
\hline $\mathrm{T}$ & 401 & 6.37 & Signal transduction mechanisms \\
\hline M & 347 & 5.51 & Cell wall/membrane/envelope biogenesis \\
\hline N & 34 & 0.54 & Cell motility \\
\hline U & 80 & 1.27 & $\begin{array}{l}\text { Intracellular trafficking, secretion, and vesicular } \\
\text { transport }\end{array}$ \\
\hline O & 158 & 2.51 & $\begin{array}{l}\text { Posttranslational modification, protein turnover, } \\
\text { chaperones }\end{array}$ \\
\hline C & 215 & 3.42 & Energy production and conversion \\
\hline G & 306 & 4.8 & Carbohydrate transport and metabolism \\
\hline E & 269 & 4.23 & Amino acid transport and metabolism \\
\hline $\mathrm{F}$ & 86 & 1.37 & Nucleotide transport and metabolism \\
\hline $\mathrm{H}$ & 193 & 3.06 & Coenzyme transport and metabolism \\
\hline I & 147 & 2.34 & Lipid transport and metabolism \\
\hline$P$ & 318 & 5.05 & Inorganic ion transport and metabolism \\
\hline Q & 93 & 1.48 & $\begin{array}{l}\text { Secondary metabolites biosynthesis, transport } \\
\text { and catabolism }\end{array}$ \\
\hline $\mathrm{R}$ & 561 & 8.92 & General function prediction only \\
\hline S & 350 & 5.56 & Function unknown \\
\hline - & 2539 & 40.35 & Not in COGs \\
\hline
\end{tabular}

Table 6 Comparison of genomes with Flammeovirga sp. SJP92, F. pacifica WPAGA $1^{\top}$ and Flammeovirga sp. OC4

\begin{tabular}{|c|c|c|c|}
\hline $\begin{array}{l}\text { Genome } \\
\text { Name }\end{array}$ & $\begin{array}{l}\text { Flammeovirga } \\
\text { sp.SJp92 }\end{array}$ & $\begin{array}{l}\text { F. pacifica } \\
\text { WPAGA1 }^{\top}\end{array}$ & $\begin{array}{l}\text { Flammeovirga } \\
\text { sp.OC4 }\end{array}$ \\
\hline Genome size (bp) & $8,534,834$ & $6,507,364$ & $8,065,497$ \\
\hline Gene count & 6,519 & 4,857 & 5,898 \\
\hline Protein coding & 6,291 & 4,739 & 5,759 \\
\hline Protein with function & 4,240 & 4,708 & 5,596 \\
\hline Plasmid number & 0 & 0 & 0 \\
\hline rRNA & 5 & 3 & 2 \\
\hline tRNA & 93 & 68 & 67 \\
\hline GC\% & 34.8 & 33.8 & 34.9 \\
\hline Contigs & 123 & 131 & 214 \\
\hline CRISPR repeats & 1 & NA & 5 \\
\hline Genes of agarase & 13 & 10 & 5 \\
\hline
\end{tabular}

Annotation of the genome indicated that this strain possessed many agarase (14 agarases at least), which was coincident with its high agar-degrading ability. Many sulfatases were also predicted and sequence alignment of proteins indicated that these sulfatases were novel. It is an aerobic strain and the existence of genes encoding superoxide dismutase and catalase were consistent with this phenotype. Flammeovirga sp. SJP92 contained many genes related to the metabolism and transport of amino acids. Also, metabolic pathway analysis and Biolog GN2 experiments illustrated that this strain could utilize many amino acids. These evidences may reflect its ability to grow by using proteinaceous media as the carbon and energy source.

\section{Conclusions}

Flammeovirga sp. SJP92 is another strain with the genome sequence of the genus Flammeovirga together with $F$. pacifica WPAGA $1^{\mathrm{T}}$ and Flammeovirga sp. OC4. It is an agar-degrading bacterium with efficient agarose liquefying ability and had an extracellular agarase system containing 14 agarases at least. These genomic data will provide insights into the mechanisms of how these agarases cooperation to degrade agar or other polysaccharide.

\section{Acknowledgments}

This work was supported by the Marine Scientific Research Foundation for Public Sector Program (No. 201105027).

\section{Authors' contributions}

LR conceived and supervised the study. QD performed the laboratory work and performed all the bioinformatics analysis with the help of HS. QD and HS drafted the manuscript and Lingwei Ruan revised the manuscript. All authors read and approved the final manuscript.

\section{Competing interests}

The authors declare that they have no competing interests.

\section{Author details}

${ }^{1}$ State Key Laboratory Breeding Base of Marine Genetic Resources, No. 184 Daxue Road, Xiamen, Fujian, People's Republic of China. ${ }^{2}$ Key Laboratory of Marine Genetic Resources of State Oceanic Administration, Third Institute of Oceanography, State Oceanic Administration, No. 184 Daxue Road, Xiamen, Fujian, People's Republic of China. ${ }^{3}$ Key Laboratory of Marine Genetic Resources of Fujian Province, No. 184 Daxue Road, Xiamen, Fujian, People's Republic of China. ${ }^{4}$ South China Sea Bio-Resource Exploitation and Utilization Collaborative Innovation Center, No. 184 Daxue Road, Xiamen, Fujian, People's Republic of China.

Received: 18 March 2016 Accepted: 7 December 2016 Published online: 26 January 2017

\footnotetext{
References

1. Nakagawa Y, Hamana K, Sakane T, Yamasato K. Reclassification of Cytophaga aprica (Lewin 1969) Reichenbach 1989 in Flammeovirga gen. nov. as Flammeovirga aprica comb. nov. and of Cytophaga diffluens (ex Stanier 1940; emend. Lewin 1969) Reichenbach 1989 in Persicobacter gen. nov. as Persicobacter diffluens comb. nov. Int J Syst Bacteriol. 1997:47:220-3.

2. Takahashi M, Suzuki K-i, Nakagawa Y. Emendation of the genus Flammeovirga and Flammeovirga aprica with the proposal of Flammeovirga arenaria nom. rev., comb. nov. and Flammeovirga yaeyamensis sp. nov. Int J Syst Evol Microbiol. 2006;56:2095-100.

3. Hosoya S, Yokota A. Flammeovirga kamogawensis sp. nov., isolated from coastal seawater in Japa. Int J Syst Evol Microbiol. 2007;57:1327-30.
} 
4. Han W, Gu J, Yan Q, Li J, Wu Z, Gu Q, et al. A polysaccharide-degrading marine bacterium Flammeovirga sp. MY04 and its extracellular agarase system. J Ocean Univ China. 2012;11:375-82.

5. Liu Y, Yi Z, Cai Y, Zeng R. Draft genome sequence of algal polysaccharides degradation bacterium, Flammeovirga sp. OC4. Mar Genomics. 2015:21:21-2.

6. Han W, Gu J, Cheng Y, Liu H, Li Y, Li F. A Novel Alginate Lyase (Aly5) from a Polysaccharide-Degrading Marine Bacterium Flammeovirga sp. MY04 Effects of Module Truncation to the Biochemical Characteristics, AlginateDegradation Patterns, and Oligosaccharide-Yielding Properties. Appl Environ Microbiol. 2015;82(1):364-74.

7. Chan Z, Wang R, Liu S, Zhao C, Yang S, Zeng R. Draft genome sequence of an agar-degrading marine bacterium Flammeovirga pacifica WPAGA1. Mar Genomics. 2015;20:23-4.

8. Xu H, Fu Y, Yang N, Ding Z, Lai Q, Zeng R. Flammeovirga pacifica sp. nov., isolated from deep-sea sediment. Int J Syst Evol Microbiol. 2012;62:937-41.

9. Field D, Garrity G, Gray T, Morrison N, Selengut J, Sterk P, et al. The minimum information about a genome sequence (MIGS) specification. Nat Biotechnol. 2008;26:541-7.

10. Wilson K. Preparation of genomic DNA from bacteria. Curr Protoc Mol Biol. 2001 Nov;Chapter 2:Unit 2.4. doi: 10.1002/0471142727.mb0204s56.

11. Li R, Li Y, Kristiansen K, Wang J. SOAP: short oligonucleotide alignment program. Bioinformatics. 2008:24:713-4.

12. Li R, Zhu H, Ruan J, Qian W, Fang X, Shi Z, et al. De novo assembly of human genomes with massively parallel short read sequencing. Genome Res. 2010;20:265-72.

13. Angiuoli SV, Gussman A, Klimke W, Cochrane G, Field D, Garrity GM, et al. Toward an online repository of Standard Operating Procedures (SOPs) for (meta) genomic annotation. OMICS. 2008;12:137-41.

14. Thompson JD, Gibson TJ, Plewniak F, Jeanmougin F, Higgins DG. The CLUSTAL_X windows interface: flexible strategies for multiple sequence alignment aided by quality analysis tools. Nucleic Acids Res. 1997;25:4876-82.

15. Tatusov RL, Fedorova ND, Jackson JD, Jacobs AR, Kiryutin B, Koonin EV, et al. The COG database: an updated version includes eukaryotes. BMC Bioinformatics. 2003:4:41.

16. Finn RD, Miller BL, Clements J, Bateman A. iPfam: a database of protein family and domain interactions found in the Protein Data Bank. Nucleic Acids Res. 2014;42:D364-D73.

17. Bendtsen JD, Nielsen H, von Heijne G, Brunak S. Improved prediction of signal peptides: SignalP 3. J Mol Biol. 2004;340:783-95.

18. Krogh A, Larsson B, Von Heijne G, Sonnhammer EL. Predicting transmembrane protein topology with a hidden Markov model: application to complete genomes. J Mol Biol. 2001;305:567-80.

19. Grissa I, Vergnaud G, Pourcel C. CRISPRFinder: a web tool to identify clustered regularly interspaced short palindromic repeats. Nucleic Acids Res. 2007:35:W52-W7.

20. Tamura K, Dudley J, Nei M, Kumar S. MEGA4: molecular evolutionary genetics analysis (MEGA) software version 4.0. Mol Biol Evol. 2007;24:1596-9.

21. Woese CR, Kandler O, Wheelis ML. Towards a natural system of organisms: proposal for the domains Archaea, Bacteria, and Eucarya. Proc Natl Acad Sci U S A. 1990:87:4576-9.

22. Krieg NR, Ludwig W, Euzéby J, Whitman WB. Bergey's Manual of Systematic Bacteriology. In: Krieg NR, Staley JT, Brown DR, Hedlund BP, Paster BJ, Ward NL, Ludwig W, Whitman WB, editors. Phylum XIV: Bacteroidetes phyl. nov, vol. 4. 2nd ed. New York: Springer; 2011. p. 25.

23. Nakagawa Y, Class IV. Cytophagia class. nov. In: Krieg NR, Staley JT, Brown DR, Hedlund BP, Paster BJ, Ward NL, Ludwig W, Whitman WB, editors. Bergey's Manual of Systematic Bacteriology, vol. 4. 2nd ed. The Bacteroidetes, Spirochaetes, Tenericutes (Mollicutes), Acidobacteria Fibrobacteres, Fusobacteria, Dictyoglomi, Gemmatimonadetes, Lentisphaerae, Verrucomicrobia, Chlamydiae, and Planctomycetes. New York: Springer; 2010. p. 370.

24. List of new names and new combinations previously effectively, but not validly, published. Int J Syst Evol Microbiol. 2012;62:1-4.

25. Leadbetter ER, Order II. Cytophagales nomen novum. In: Buchanan RE, Gibbons NE, editors. Bergey's Manual of Determinative Bacteriology. 8th ed. Baltimore: The Williams and Wilkins Co.; 1974. p. 99.

26. Skerman VBD, McGowan V, Sneath PHA, Moore WEC, Moore LVH. Approved Lists. Int J Syst Bacteriol. 1980; 30:225-420.
27. Yoon J, Adachi K, Park S, Kasai H, Yokota A. Aureibacter tunicatorum gen. nov., sp. nov., a marine bacterium isolated from a coral reef sea squirt, and description of Flammeovirgaceae fam. nov. Int J Syst Evol Microbiol. 2011:61:2342-7.

28. Ashburner M, Ball CA, Blake JA, Botstein D, Butler H, Cherry JM, et al. Gene Ontology: tool for the unification of biology. Nat Genet. 2000;25:25-9.

\section{Submit your next manuscript to BioMed Central and we will help you at every step:}

- We accept pre-submission inquiries

- Our selector tool helps you to find the most relevant journal

- We provide round the clock customer support

- Convenient online submission

- Thorough peer review

- Inclusion in PubMed and all major indexing services

- Maximum visibility for your research

Submit your manuscript at www.biomedcentral.com/submit
Biomed Central 